\title{
ECONOMIC SECURITY OF THE STATE: EXPERIENCE OF DEVELOPED COUNTRIES OF THE WORLD
}

\section{ЕКОНОМІЧНА БЕЗПЕКА ДЕРЖАВИ: ДОСВІД РОЗВИНУТИХ КРАЇН СВІТУ}

\section{Hbur Zoriana ${ }^{1}$}

DOI: http://dx.doi.org/10.30525/978-9934-571-28-2_7

\begin{abstract}
The article considers approaches to the interpretation of the notion of economic security. The main functions of economic security are described, which are divided into five groups: protective, regulatory, preventive, innovative and social. The system of security of the state economy is analyzed, which is represented by internal and external subsystems that have their components. The main elements of the external security subsystem are technological, commercial, and financial. The subsystem of internal security includes industrial-technical, raw materials, energy, environmental, information components. In accordance with this, internal and external threats to the economic security of the state have been identified, which cause an insufficient level of stability in the economy, and as a consequence, a decrease in the level of economic security of any state. The main approaches to ensuring economic security in European countries are considered, and the dynamics of the index of global economic competitiveness of European countries in 2016-2017 is analyzed.

Economic security is a complex and multifactorial system, which is the material basis for other components formation within the national security. Ensuring economic security is one of the main problems of the state, since the emergence of numerous socio-economic problems in the country, as a rule, exists due to the inability of the state to take preventive measures or their implementation. While taking into account all the above information, the state should ensure the corresponding level of security that guarantees internal and external stability required for normal economic functioning and the country's active participation in international division of labor and competitiveness, and at the same time creating the basis for ensuring an adequate level of security.
\end{abstract}

${ }^{1} \mathrm{PhD}$ in Public Administration, Postdoctoral Student, National Academy of Public Administration under the President of Ukraine, Ukraine 
A lot of scientific works are devoted to the state economic security conditions. In particular, we should note the scientific achievements of the following researchers: V.B. Averyanov, V.G. Atamanchuk, O.M. Bandurka, Yu.P. Bytiak, L.V. Koval, S.I. Lekar, V.F. Opryshko, G.Kh. Popov, V.M. Shapoval, Yu.S. Shemshuchenko, L.P. Yuzkov and others.

The purpose of this article is to study foreign experience in ensuring the country's economic security trough systematizing and generalizing the approaches of different countries to the solution of this problem.

\section{1. Вступ}

Економічна безпека - це складна і багатофакторна система, яка представляє собою матеріальну основу для формування інших компонентів національної безпеки. Забезпечення економічної безпеки є однією з головних проблем держави, оскільки виникнення численних соціально-економічних проблем в країні, як правило, обумовлено неможливістю держави вживати запобіжні заходи або своєчасне їх здійснення. 3 огляду на це, держава повинна забезпечити такий рівень безпеки, який гарантуватиме внутрішню і зовнішню стабільність, необхідну для нормального економічного функціонування, активну участь країни в міжнародному розподілі праці та конкурентоспроможність, одночасно це створить основу для забезпечення достатнього рівня безпеки.

Питанню забезпечення необхідних умов для економічної безпеки держави присвячено чимало наукових праць. Зокрема, варто відзначити наукові здобутки таких дослідників: В. Б. Авер'янова, В. Г. Атаманчука, О. М. Бандурки, Ю. П. Битяка, Л. В. Коваля, С. І. Лекаря, В. Ф. Опришка, Г. Х. Попова, В. М. Шаповала, Ю. С. Шемшученка, Л. П. Юзькова та ін.

Метою статті є дослідження зарубіжного досвіду забезпечення економічної безпеки держави шляхом систематизації та узагальнення підходів різних країн до вирішення даного завдання.

\section{2. Поняття «економічна безпека» у зарубіжній та вітчизняній літературі}

Забезпечення безпеки особистості, суспільства й держави, усього світового співтовариства є ключовою цивілізаційною метою сучасного етапу розвитку світового господарства. 


\section{Hbur Zoriana}

Варто погодитися зі Скорук О. В., яка зазначає, що у зарубіжній та вітчизняній літературі існує багато підходів до тлумачення поняття економічної безпеки держави за допомогою таких характеристик [9]:

- стійкість та стабільність, протидія внутрішнім і зовнішнім загрозам, під якими розуміємо міцність і надійність зв'язків між усіма елементами економічної системи, стабільність економічного розвитку держави, стійкість до стримування та знешкодження дестабілізуючих загроз-факторів;

- економічна незалежність, що характеризує насамперед можливість для будь-якого суб'єкта економічної безпеки самостійно приймати і реалізовувати стратегічні економічні та політичні рішення для розвитку, можливість використовувати національні конкурентні переваги для забезпечення стабільності та розвитку;

- самовідтворення та саморозвиток. Ця характеристика передбачає створення необхідних умов для ведення ефективної економічної політики та розширеного само відтворення, забезпечення конкурентоспроможності національної економіки на світовій арені;

- національні інтереси. Ця характеристика визначає спроможність національної економіки захищати національні економічні інтереси.

Світовий досвід вказує на те, що без активної регулюючої ролі держави не може бути ефективної, соціально орієнтованої ринкової економіки, не говорячи вже про ефективність забезпечення економічної безпеки країни. Немає жодної країни з високорозвиненою економікою, де б держава усунулася від регулювання ключових соціально-економічних процесів [3].

Як правило, економічна безпека держави виступає як система, основні функції якої поділяються на п'ять груп: захисна, регуляторна, попереджувальна, інноваційна та соціальна.

1. Захисна функція виражається здатністю захищати державну економічну систему від внутрішніх та зовнішніх загроз. Реалізація цієї функції безпосередньо пов'язана з формуванням економічного ресурсного потенціалу та його ефективним використанням.

2. Функція регулювання з'являється в різних економічних підсистемах шляхом забезпечення економічної безпеки держави та застосування функціональних механізмів, спрямованих на нейтралізацію ризиків. 
3. Попереджувальна функція державної економічної безпеки зосереджена на передбаченні виникнення потенційних кризових ситуацій під час економічної діяльності та підготовці економічної системи до їхнього протистояння. Це передбачає соціально-економічні та організаційно-технічні заходи, результатом яких $є$ зміцнення оборонної функції системи.

4. Інноваційна функція діє через нетрадиційні рішення держави щодо економічних процесів та інноваційних рішень, спрямованих на прискорення темпів економічного розвитку або на нейтралізацію можливих негативних наслідків останнього. Результати цієї функції виникають в економіці опосередковано i, як правило, виражаються у вигляді підвищення ефективності інших функцій безпеки.

5. Соціальна функція системи державної економічної безпеки передбачає повне задоволення вимог усіх членів суспільства та повного узгодження інтересів. Реалізація цієї функції сприяє підвищенню рівня та якості життя та гарантує захист прав та свобод громадян.

Слід зазначити, що така класифікація функцій державної системи економічної безпеки є загальноприйнятою, оскільки ці функції взаємопов'язані та взаємозалежні, і часто завдання однієї функції можуть повторюватися при визначенні іншої функції. Ефективність забезпечення державної економічної безпеки залежить від можливості повного функціонування цих функцій разом і одночасно. Крім того, проблеми цих функцій можуть бути змінені у забезпеченні окремих компонентів економічної безпеки.

Система безпеки державної економіки представлена внутрішніми та зовнішніми підсистемами, які мають свої компоненти (див. рис. 1):

- підсистема зовнішньої безпеки - технологічна, комерційна, фінансова

- підсистема внутрішньої безпеки - промислово-технічна, сировинна, енергетична, екологічна, інформаційна.

Отже, технологічний компонент державної економічної безпеки характеризується активною участю у міжнародному науково-технічному прогресі, що гарантує здатність держави застосовувати найновіші технологічні рішення у вітчизняному виробництві та забезпечує конкурентоспроможність виробництва національних товарів та послуг на міжнародному ринку. 


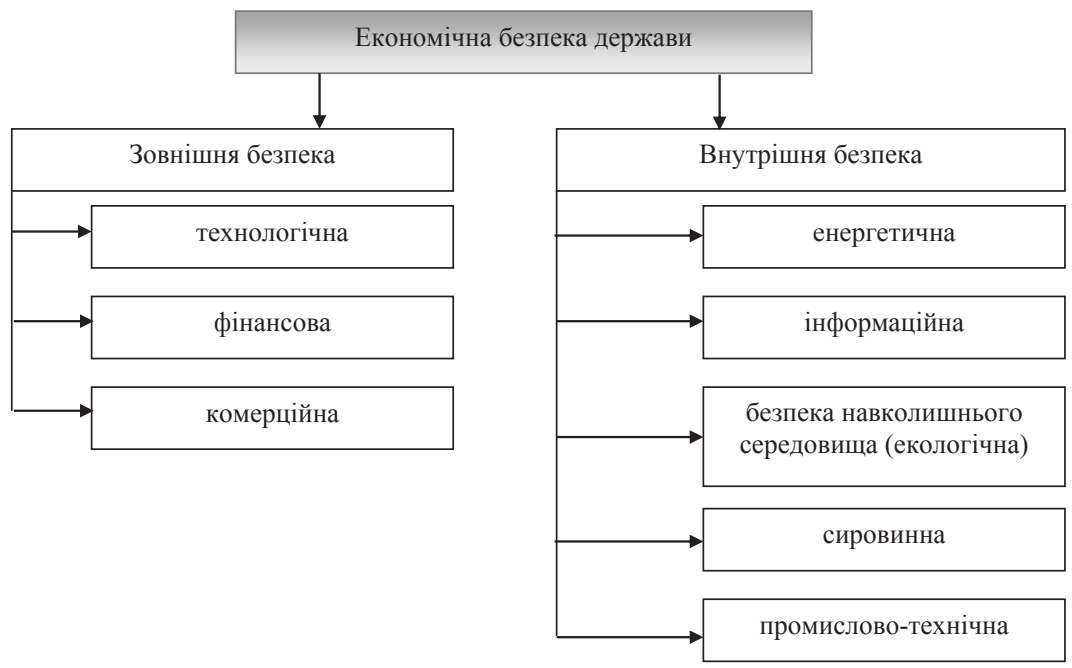

\section{Рис. 1. Структура економічної безпеки держави}

Джерело: власна розробка автора

Комерційна складова державної економічної безпеки є великою гарантією диверсифікації структури експортної та імпортної торгівлі в країні. В умовах географічної диверсифікації експорт та імпорт країни не будуть залежати від впливу одного чи декількох великих центрів.

Фінансовий компонент державної економічної безпеки можна визначити як здатність країни впроваджувати незалежну монетарну політику та забезпечити стабільне функціонування фінансової системи шляхом відшкодування міжнародних кредитів та отримання, розподілу, використання та повернення іноземних інвестицій за наявності несприятливих зовнішніх та внутрішніх умов.

Значення промислово-технічної складової державної економічної безпеки веде до забезпечення виробничих та технічних можливостей впровадження розширеного відтворення економіки. Це передбачає здатність економіки відповідати потребам суспільства, навіть у ситуаціях, коли порушуються зовнішні або внутрішні економічні сприятливі умови.

Сировинна складова державної економічної безпеки передбачає економічну гарантію необхідної кількості продовольства та сировини. 
Забезпечення харчових продуктів та сировини є однією 3 найважливіших складових державної економічної безпеки, а в багатьох країнах світу існують закони, що визначають мінімальні стандарти забезпечення продовольчої безпеки.

Наступним компонентом державної економічної безпеки є енергетична безпека, що передбачає стабільне постачання достатньої кількості необхідної енергії для внутрішнього споживання. Для цього аналізи проводяться послідовно у всіх країнах, виявляючи обставини, поява яких може підірвати діяльність країни в галузі паливно-енергетичної системи.

Екологічною складовою державної економічної безпеки є здатність держави запобігати та усунути розрив між суспільними інтересами та захистом довкілля вчасно. Проблема забруднення навколишнього середовища тісно пов'язана $з$ економічною діяльністю людини, тому для екологічної безпеки необхідно мінімізувати антропогенний вплив на озоновий шар, флору та фауну, генофонд та інші компоненти навколишнього середовища.

Інформаційна складова державної економічної безпеки у випадку наявних внутрішніх та зовнішніх зв'язків передбачає таку економічну діяльність, внаслідок якої надійність обміну інформацією, збільшення частки нематеріальних активів у національне багатство.

Відповідно до розглянутих складових виділяють внутрішні та зовнішні загрози економічній безпеці держави, які зумовлюють недостатній рівень стабільності економіки, а як наслідок і відповідно зниження рівня економічної безпеки будь-якої держави. До зовнішніх загроз слід віднести наступні: нестабільність національної валюти, що відбувається під час нестабільної ситуації в економіці, в період кризи; скорочення іноземних інвестицій; нестабільні умови зовнішньої торгівлі; великий зовнішній борг, що є тягарем для нашої країни та депресивно впливає на розвиток економіки; залежність держави в сфері стабільності постачання енергоносіїв тощо.

До основних внутрішніх загрозам слід віднести: незначну частку інноваційної продукції; неефективне державне регулювання економіки, тобто невідповідність завданням економічного зростання; низьку конкурентоспроможність продукції; корупцію; невисокий рівень життя більшої частини населення, як наслідок нерівномірності розвитку територій, поширення масштабів незайнятості, вплив світо- 


\section{Hbur Zoriana}

вої фінансової кризи і т. д.; витік капіталу за кордон також є фактором, який чинить певний вплив на економічну безпеку тощо.

Як зауважує Притула Н.В. [3], узагальнення зарубіжного досвіду показує, що забезпечення економічної безпеки у масштабах національної економіки істотно впливає на міжнародний авторитет країни. У свою чергу Мельник В.І. [2] додає, що більшість стратегій національної безпеки держав оріснтована на забезпечення національної та економічної безпеки через проведення радикальних економічних реформ, тісну інтеграцію до світових та європейських систем безпеки, приєднання до економічних і політичних союзів та організацій. У зв'язку з цим застосування позитивного досвіду зарубіжних країн щодо забезпечення економічної безпеки має стати одним з найважливіших напрямків розвитку національної економіки України. Розглянемо основні підходи до забезпечення економічної безпеки у країнах Європи (див. табл. 1).

Таким чином, у кожній країні сформовано власне уявлення про економічну безпеку і відповідно про методи іiі забезпечення, які можуть бути спрямовані на досягнення національних, суспільних інтересів або на стійкість економічного розвитку, або на незалежність національної економіки від зовнішнього ринку. Пугач О.А. [8] також підкреслює, що спільною характеристикою та основою представлених систем економічної безпеки в різних країнах $\epsilon$ нормативно-правова база з регулювання внутрішніх та зовнішньо-економічних операцій, в тому числі стосовно участі іноземного капіталу в національній економіці, а також інституціональне забезпечення захисту національних економічних інтересів в умовах міжнародної інтеграції.

Основним показником, який характеризує рівень економічної безпеки за умови його підвищення $є$ індекс економічної конкурентоспроможності. Відповідно до розглянутої характеристики проаналізуємо індекси глобальної економічної конкурентоспроможності вище загаданих країн у 2016-2017 pp.

Відповідно до наведених даних у табл. 2 можемо констатувати факт, що обрані напрямки забезпечення економічної безпеки у країнах Європи здебільшого позитивно впливають на рівень економічної конкурентоспроможності цих країн. Зокрема, зайняли вищий рівень у рейтингу такі країни як: Німеччина, індекс економічної конкурентоспроможності якої зріс на 0,04 пункти, Франція - 3,07 пунктів, Велико- 


\section{Порівняльна характеристика підходів до забезпечення економічної безпеки у країнах Свропи}

\begin{tabular}{|c|c|}
\hline Країна & Характеристика \\
\hline \multicolumn{2}{|c|}{ I. Країни Західної Свропи,у т.ч.: } \\
\hline Німеччина & $\begin{array}{l}\text { Спеціальна законодавча база щодо забезпечення ЕБ відсутня. } \\
\text { Основні питання з цієї проблеми відображаються в директивах } \\
\text { Міністерства оборони, які регламентують найважливіші сфери } \\
\text { ринкової діяльності та визначають контрольні функції держави. } \\
\text { Використовуються методи щодо забезпечення ЕБ, які спрямовані на } \\
\text { підтримку цивілізованих ринкових відносин, забезпечення еконо- } \\
\text { мічного і соціального прогресу, недопущення монополізму в окре- } \\
\text { мих галузях, створення умов для справедливої конкуренції та ста- } \\
\text { більності національної валюти, захист від економічного шантажу. }\end{array}$ \\
\hline Франція & $\begin{array}{l}\text { Спеціальна законодавча база щодо забезпечення ЕБ відсутня. Окремі } \\
\text { положення щодо ЕБ (створення умов для підвищення національного } \\
\text { добробуту і зміцнення економічного потенціалу країни) відображені } \\
\text { в Законі «Про національну безпеку». Методи щодо забезпечення ЕБ } \\
\text { спрямовані на зниження вразливості господарської системи країни, } \\
\text { збереження самостійності зовнішньої політики, усунення диспро- } \\
\text { порцій у рівні економічного розвитку суб'єктів господарювання; } \\
\text { недопущення надмірної зовнішньої залежності в найважливіших } \\
\text { секторах економіки, мінімізацію ризиків, пов'язаних із залежністю } \\
\text { від зовнішнього світу. }\end{array}$ \\
\hline $\begin{array}{l}\text { Велико- } \\
\text { британія }\end{array}$ & $\begin{array}{l}\text { Спеціальна законодавча база щодо забезпечення ЕБ відсутня. } \\
\text { Окремі норми, які регламентують ЕБ, містяться у нормативно-пра- } \\
\text { вових актах у сфері оборонної політики. Вони грунтуються на оцін- } \\
\text { ках національних інтересів і реалізуються через їх захист. Методи } \\
\text { щодо забезпечення ЕБ пов'язані з прогнозуванням і запобіганням } \\
\text { найбільш небезпечних зовнішніх і внутрішніх ризиків. При виро- } \\
\text { бленні та реалізації рішень, що відносяться до забезпечення ЕБ, } \\
\text { акцент робиться на спеціалізовані організації, що представляють } \\
\text { інтереси промисловців і підприємців. }\end{array}$ \\
\hline Іспанія & $\begin{array}{l}\text { Законодавча база щодо забезпечення ЕБ відрізняється гнучкістю, } \\
\text { в ній чітко визначено функції органів управління та організацій } \\
\text { у даній сфері, якими розробляються спеціальні програми еконо- } \\
\text { мічного розвитку. Нормативно-правові акти щодо забезпечення } \\
\text { ЕБ пов'язані з відповідним законодавством СС. Методи щодо } \\
\text { забезпечення ЕБ захищають інтереси пріоритетних галузей про- } \\
\text { мисловості, а також спрямовані на стимулювання інвестицій, } \\
\text { забезпечення валютного контролю, на розробку законодавства про } \\
\text { акціонерні товариства. }\end{array}$ \\
\hline
\end{tabular}


Закінчення таблиці 1

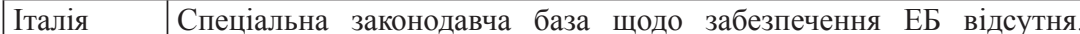
У діяльності по забезпеченню ЕБ Італія керується укладеними нею міжнародними угодами. Методи щодо забезпечення ЕБ спрямовані насамперед на захист інтересів національних виробників на внутрішньому і зовнішньому ринках.

П. Країни Центральної Свропи, у т.ч.:

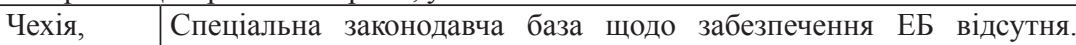
Болгарія, Забезпечення ЕБ орієнтується на відповідні нормативно-правові Угорщина, акти СС. При виборі методів забезпечення ЕБ країни враховують Польща, геополітичну ситуацію, вектор і стратегію розвитку економіки відСловакія повідно до тенденцій регіонального та світового еволюційного процесу, напрямок економічних реформ.

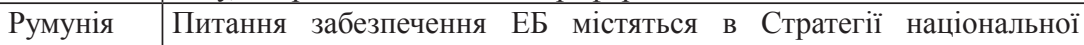
безпеки. Основними напрямами забезпечення ЕБ є: здійснення ефективних заходів макроекономічної стабілізації, прискорення структурних реформ в економіці, створення приватного сектора, залучення іноземних інвестицій та підтримка малого і середнього бізнесу; узгодження фінансово-економічного законодавства, фінансової, економічної і митної політики із законодавством ЄС тощо.

Ш. Країни Східної Свропи, у т.ч.:

Російська $\quad$ Забезпечення ЕБ регулюють Концепція національної безпеки РФ; Федерація Державна стратегія економічної безпеки РФ; Закон РФ «Про безпеку». Відмінною рисою законодавства $є$ наявність у ньому регіонального аспекту та положень про формування критеріїв і показників оцінки стану економічної безпеки. Методи забезпечення ЕБ зорієнтовані на реалізацію економічних реформ на найближчу перспективу, зменшення небезпеки зростання нерівномірності соціально-економічного розвитку регіонів.

Республіка Законодавчо ЕБ відображається у Концепції національної безпеки Білорусь Білорусі. До пріоритетних напрямків забезпечення ЕБ відносяться: розвиток системи економічних відносин, створення механізмів розв'язання виникаючих у суспільстві протиріч та скасування передумов їх виникнення; розробка стратегії забезпечення реалізації життєво важливих економічних інтересів у країні; формування довгострокової програми економічних перетворень; забезпечення сталого соціально-економічного розвитку; використання неінфляційних методів фінансування дефіциту бюджету та ефективний перерозподіл фінансових ресурсів; удосконалення зовнішньоекономічної політики; створення сприятливих умов для підприємницької діяльності та ін.

Латвія, Спеціальна законодавча база щодо забезпечення ЕБ відсутня. Литва, Забезпечення ЕБ орієнтується на відповідні нормативно-правові Естонія акти СС. Методи забезпечення ЕБ спрямовані насамперед на реалізацію фінансово-економічної безпеки.

Джерело: складено автором на основі [1; 6] 
Economic security of the state: experience of developed countries of the...

Таблиця 2

Динаміка індексу глобальної економічної конкурентоспроможності європейських країн у 2016-2017 pp.

\begin{tabular}{|c|c|c|c|c|c|c|}
\hline \multirow[t]{2}{*}{ Країна } & \multicolumn{2}{|c|}{ 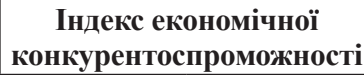 } & \multicolumn{2}{|c|}{$\begin{array}{c}\text { Місце у } \\
\text { рейтингу }\end{array}$} & \multicolumn{2}{|c|}{$\begin{array}{c}\text { Абсолютне } \\
\text { відхилення, +/- }\end{array}$} \\
\hline & 2016 & 2017 & 2016 & 2017 & I e.к. & $\mathbf{R}$ \\
\hline \multicolumn{7}{|c|}{ I. Країни Західної Європи,у т.ч.: } \\
\hline Німеччина & 5,53 & 5,57 & 5 & 4 & 0,04 & -1 \\
\hline Франція & 2,13 & 5,20 & 22 & 21 & 3,07 & -1 \\
\hline Великобританія & 5,43 & 5,49 & 10 & 7 & 0,06 & -3 \\
\hline Іспанія & 4,59 & 4,68 & 33 & 32 & 0,09 & -1 \\
\hline Італія & 4,46 & 4,50 & 43 & 44 & 0,04 & 1 \\
\hline \multicolumn{7}{|c|}{ II. Країни Центральної Європи, у т.ч.: } \\
\hline Чехія & 4,69 & 4,72 & 31 & 31 & 0,03 & 0 \\
\hline Болгарія & 4,32 & 4,44 & 54 & 50 & 0,12 & -4 \\
\hline Угорщина & 4,25 & 4,20 & 63 & 69 & $-0,05$ & 6 \\
\hline Польща & 4,49 & 4,56 & 41 & 36 & 0,07 & -5 \\
\hline Словакія & 4,22 & 4,28 & 67 & 65 & 0,06 & -2 \\
\hline Румунія & 4,32 & 4,30 & 53 & 62 & $-0,02$ & 9 \\
\hline Україна & 4,03 & 4,00 & 79 & 85 & $-0,03$ & 6 \\
\hline \multicolumn{7}{|c|}{ III. Країни Східної Свропи, у т.ч.: } \\
\hline $\begin{array}{l}\text { Російська } \\
\text { Федерація }\end{array}$ & 4,44 & 4,51 & 45 & 43 & 0,07 & -2 \\
\hline Латвія & 4,45 & 4,45 & 44 & 49 & 0 & 5 \\
\hline Литва & 4,55 & 4,60 & 36 & 35 & 0,05 & -1 \\
\hline Естонія & 4,74 & 4,78 & 30 & 30 & 0,04 & 0 \\
\hline
\end{tabular}

Джерело: складено автором на основі [7]

британія - 0,06 пунктів, Іспанія - 0,09 пунктів, Болгарія - 0,12 пунктів, Польща - 0,07 пунктів, Російська Федерація - 0,07 пунктів та Литва на 0,05 пунктів. Однак ряд інших країн погіршили значення даного показника та зменшили свій рейтинг, а саме: Угорщина, індекс економічної конкурентоспроможності якої зменшився на 0,05 пунктів та Румунія - 0,02 пункти.

\section{3. Забезпечення економічної безпеки у розвинутих країнах світу}

У Великобританії економічна безпека $є$ частиною оборонної політики, яка направлена на дотримання національних інтересів. Національні інтереси у сфері економіки - це господарські інтереси 


\section{Hbur Zoriana}

всього суспільства, пріоритетні відносно інших форм суспільних інтересів [6].

Розподіл загроз економічній безпеці країни на зовнішні та внутрішні дозволяє виокремлювати найбільш вірогідні і найбільш важливі з них, і спрямовувати зусилля на їх подолання. Максимальне сприяння надається приватному бізнесу, ефективний розвиток якого має забезпечити національну економічну безпеку.

3 метою забезпечення ефективної взаємодії між парламентом, урядом і великим бізнесом у Великобританії створена система інститутів, яка дозволяє розробляти і реалізовувати рішення національної ваги щодо економічної безпеки. До цієї системи входять Конфедерація британської промисловості, Рада торгівлі зі Східною Європою, ряд спеціалізованих організацій, які представляють інтереси промисловців та підприємців [6].

В Іспанії необхідність забезпечення економічної безпеки держави визначено нормативними актами. Зокрема, здійснено чіткий розподіл компетенції у цій сфері серед міністерств та відомств. Законодавчо затверджується програма економічних пріоритетів на кожен етап розвитку економічної сфери. Створені спеціальні державні служби контролю виконання програми. Загалом економічна безпека в Іспанії формується відповідно до завдань ії забезпечення у Євросоюзі. Стійкий розвиток економіки Іспанії забезпечують пріоритетні галузі національної економіки, які перебувають під захистом державної протекціоністської політики. Для цього призначений спеціальний закон «Про вдосконалення і захист національної промисловості», який визначає митні тарифи, порядок залучення іноземних технологій, пріоритет національних товарів у торгівлі. На державному рівні регулюються процедури стимулювання інвестицій в економіку, валютні процедури, діяльність акціонерних товариств, створення захисних бар'єрів для певних галузей.

В Іспанії діяв закон про іноземні інвестиції, в якому визначалися сфери, куди не допускався іноземний капітал (засоби масової інформації, об'єкти оборони), сектори економіки з обмеженим доступом іноземного капіталу (банківська діяльність, стратегічні галузі, туризм), відкриті сектори економіки (виробництво продовольчих товарів, автомобільна промисловість) [7].

У таких західноєвропейських країнах як Данія, Бельгія, Нідерланди, Люксембург основною стратегічною ціллю щодо захисту наці- 
ональних економічних інтересів є забезпечення стійкого економічного зростання і модернізація економіки відповідно до умов конкуренції на світовому ринку [5].

У «нових» країнах Євросоюзу, зокрема, Чехії, Словакії, Словенії, Польщі основні засади економічної безпеки тісно пов'язані з економічними інтересами Євросоюзу. Відповідно, завдання забезпечення економічної безпеки включають базові кількісні показники розвитку, коректовані для кожної країни. Усі економічні реформи мають на меті зближення національних інтересів з європейськими.

3 початку становлення вільних національних економік у цих країнах була обрана подібна модель забезпечення економічної безпеки. Можна вважати, що вони успішно подолали проблеми формування демократичних і ринкових інституцій. Чехія, Словенія і Словакія взагалі наближуються в економічному розвитку до таких «старих» країн Євросоюзу, як Греція, Іспанія, Португалія.

На сучасному етапі розвитку напрями економічної політики національної безпеки Чехії: забезпечення економічного зростання, розвиток економіки та міжнародного співробітництва; підтримка внутрішньої та зовнішньої стабільності; протидія інфляційним стрибкам; підтримка позитивного сальдо зовнішньої торгівлі; ефективне ринкове регулювання в економічній та фінансовій сферах; боротьба зі злочинністю [5].

Сучасні зовнішні загрози Польщі в економічній сфері пов'язані 3 економічною нестабільністю країн на східному рубежі. Після надання безвізового режиму Україні значно загострилася проблема трудової міграції, яка може порушити соціально-економічну стабільність країни. Разом з тим невизначеними стають фінансово-економічні ризики. Відповідно, потребують корективи положення «Стратегія безпеки Республіки Польща» [9].

Основні аспекти забезпечення економічної безпеки в приєднаних країнах-членах Європейського Союзу визначені в стратегіях нацбезпеки.

Японський підхід до проблеми забезпечення економічної безпеки базується на таких принципах:

- розвиток економічного потенціалу країни;

- формування та утримання економічних переваг країни у світі;

- формування такого глобального середовища, що сприятиме максимальній реалізації національних інтересів. 


\section{Hbur Zoriana}

В Японії доктрина національних інтересів включає три головні аспекти: суспільна безпека (внутрішній соціальний аспект), національна безпека (військовий аспект), мир і глобальна стабільність у світі (зовнішньополітичний аспект).

Політика національної економічної безпеки Японії вкінці минулого століття була спрямована на приведення іiї зовнішньополітичної ролі у світі у відповідність з їі економічним потенціалом [10, с. 38]. Після досягнення цієї мети Японія у сфері економічної безпеки концентрується на створенні зовнішніх умов безпечного функціонування та розвитку власної економіки у сучасному глобалізованому світі.

Сучасні пріоритети політики економічної безпеки Японії: високий рівень конкурентоспроможності експорту, підвищення продуктивності праці, диверсифікування сировинних, паливно-енергетичних і продовольчих ресурсів, забезпечення завдяки цьому їх стабільного надходження, розширення співробітництва 3 «корисними» (стратегічно важливими) державами. В результаті реалізації такої політики економічна могутність Японії зміцнюється, економічна безпека зростає.

Суттєвим елементом забезпечення економічної безпеки Японії $є$ нарощення науково-технічного потенціалу. Держава здійснює політику заохочення використання наукомістких технологій, фінансування науково-дослідних та дослідно-конструкторських робіт (НДДКР). Така політика характерна для всіх високорозвинених країн світу (рис. 2).

У США 3 метою вжиття відповідних заходів щодо забезпечення економічної безпеки президентом у грудні 1990р. був завтерджений меморандум, у якому викладався основний зміст Національної програми забезпечення економічної безпеки. Результатом розробки програми вкінці 1993 року стало створення єдиної в масштабах країни і взаємозалежної у всіх іiі елементах централізованої системи економічної безпеки, спрямованої на збереження лідерства США в технологічних областях і забезпечення економічних інтересів країни [9, с. 51].

Детальним опрацюванням програми і визначенням механізму іiі впровадження в практику займалась Міжвідомча робоча група представників уряду і промисловості, у яку входили заступник міністра оборони, міністр енергетики, заступник директора ЦРУ, представники ФБР і АНБ, керівники провідних фірм і компаній, загальною чисельністю 260 осіб. 


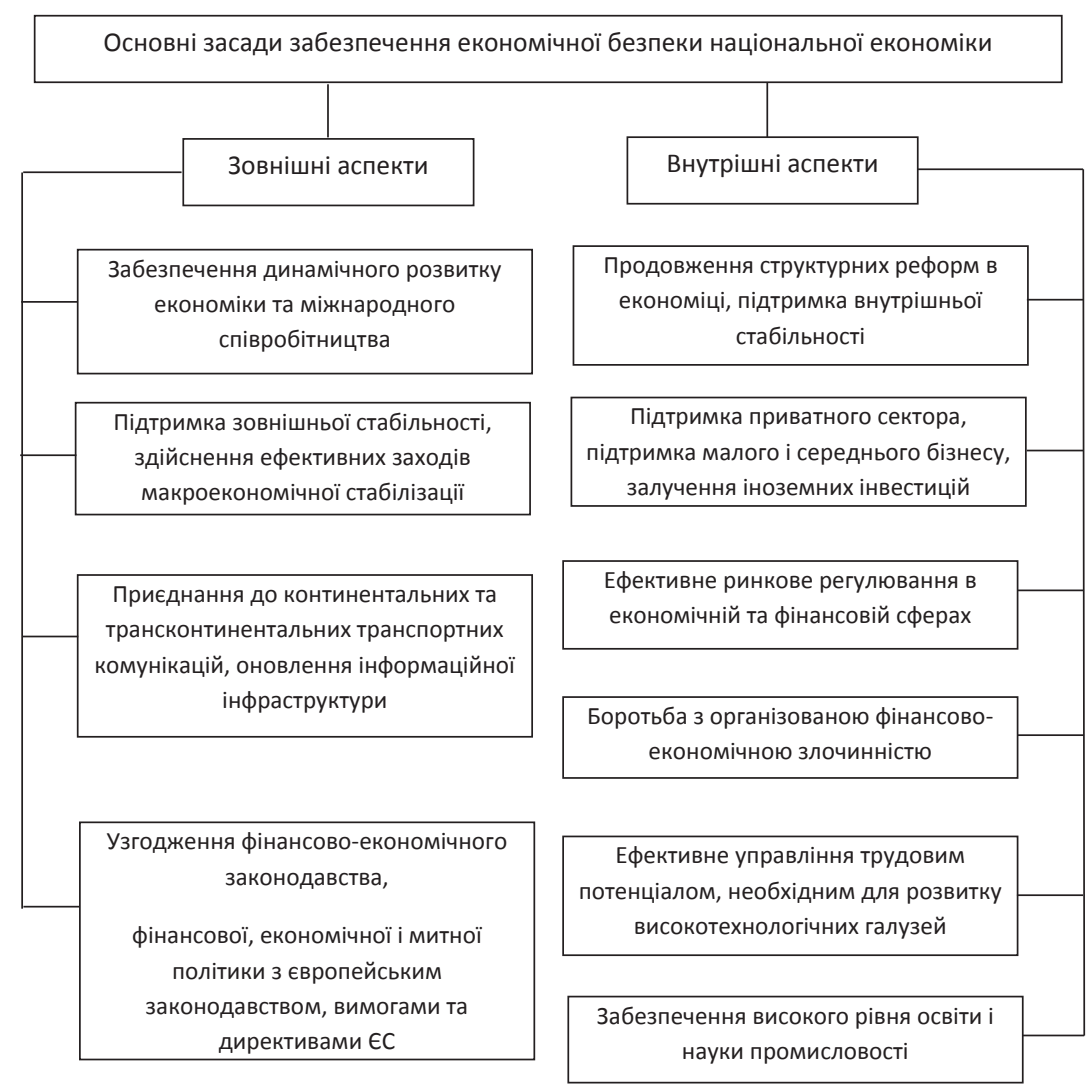

\section{Рис. 2. Частка витрат на НДДКР (\% до ВВП) і обсяг ВВП (тис. дол. на душу населення) у розвинутих країнах світу та Украйні Джерело: складено за [11]}

Вказаною міжвідомчою групою визначені параметри загальної політики в області економічної безпеки і її сучасні критерії, відповідно д яких засновуються вихідна $з$ єдиного центра система управління i єдиний порядок контролю й звітності: вводяться в дію заходи, що забезпечують постійну оцінку діяльності персоналу, що має допуск до таємної інформації, для того щоб вчасно виявити осіб, потенційно уразливих для вербальної розробки іноземними спецслужбами. Цією ж групою вироблено методологію для визначення вартості всіх заходів 


\section{Hbur Zoriana}

щодо забезпечення економічної безпеки, вводиться в дію система відстеження й оцінки щорічних витрат. Розроблено механізм управління системою забезпечення економічної безпеки, запропоновані проекти нових інструкцій та директивів, внесені зміни в систему підготовки і перепідготовки кадрів, забезпечені можливості підвищення по службі урядових чиновників, що займаються питаннями економічної безпеки. Адміністрація США підтвердила пріоритетне значення заходів економічної безпеки. Проблема захисту таємниць у сфері економіки піднята у США до рівня проблеми Національної безпеки і як така стоїть під контролем у Президента і Ради національної безпеки [9, с. 18-19].

У Японії, одній з провідних країн сучасного світу, до теперішнього часу діє концепція Комплексного забезпечення національної безпеки. Цей програмний документ був розроблений групою японських експертів і схвалений Кабінетом міністрів ще у 1980p. і з цього часу служить концептуальною основою політики правлячих кіл Японії у всіх областях, особливо у забезпеченні економічної безпеки. Згідно з концепцією основою забезпечення економічної безпеки $є$ захист від будь-яких форм та прояві зовнішніх загроз. Забезпечення економічної безпеки в Японії здійснюється вжиттям комплексу заходів, спрямованих на усунення загроз, а також на протидію тим загрозам, усунення яких поки що неможливо з тих чи інших причин [9].

У Великобританії основні аспекти забезпечення національної безпеки регламентуються, в основному, таємними директивами уряду, розпорядженнями й інструкціями відповідних міністерств. У Великобританії немає єдиної програми забезпечення економічної безпеки, однак окремі іiі аспекти відображені в ряді законів, зокрема у законах про захист державних таємниць. Забезпечення режиму таємності на промислових підприємствах Великобританії здійснюється службами безпеки відповідних міністерств, що разом 3 англійською контррозвідкою, розробляють свої правила охорони таємниць і вирішують питання допуску співробітників до роботи із таємними матеріалами. Разом $з$ контрактом кожна фірма отримує так званий лист про таємні аспекти [10, с. 34].

У Франції питання забезпечення економічної безпеки відображені у Законі про національну безпеку 1964p. Крім того, існує ряд декретів і розпоряджень президента країни і прем'єр-міністра. У ФРН діяльність спеціальних служб по забезпеченню економічної безпеки рег- 
ламентована низкою законів, постанов і настанов. Однак єдиної програми забезпечення економічної безпеки у ФРН не розроблено. Лише iii окремі положення існують у прийнятому бундестагом законі про охорону конституції, якому визначений порядок захисту таємниць на режимних підприємствах.

Для країн-членів СНД характерне відокремлення економічної складової серед сфер національної безпеки, підвищена увага приділяється внутрішнім чинникам економічних небезпек та чіткій систематизації за сферами національної безпеки. Світовий досвід розв'язання проблем економічної безпеки переконливо свідчить про необхідність удосконалення концептуального забезпечення економічної безпеки у зовнішньоекономічній сфері України, використання позитивних ознак глобалізації для цілей суспільного розвитку держави та пріоритетності забезпечення національних економічних інтересів при формуванні зовнішньої та внутрішньої політики.

Досвід країн Центральної і Східної Свропи базується на орієнтації процесу забезпечення економічної безпеки через проведення радикальних економічних реформ, тісну інтеграцію у світові та європейські системи безпеки, приєднання до економічних і політичних союзів та організацій.

\section{4. Методологія дослідження}

Методологічну основу статті становлять загальнонаукові прийоми дослідження і методи, що грунтуються на сучасних наукових засадах управлінської, юридичної і споріднених із ними наук.

У роботі використано такі методи:

- системний підхід - для дослідження і формулювання поняття економічна безпека, система економічної безпеки та загрози економічній безпеці України;

- метод аналізу і синтезу - для аналізу та опису динаміки індексу глобальної економічної конкурентоспроможності європейських країн у 2016-2017 pp.;

- монографічний - для опису зарубіжного досвіду забезпечення економічної безпеки;

- логічний метод - для дослідження еволюції постановки проблеми й наступності іiі вирішення, для встановлення зв'язків між суспільними явищами та подіями. 


\section{Hbur Zoriana}

\section{5. Пошуки}

Здійснивши аналіз систем економічної безпеки країн 3 найвищим економічним розвитком можна дійти до висновку, що найбільш ефективними $є$ системи забезпечення економічної безпеки в таких країнах Європейського Союзу, як Німеччина, Франція, Великобританія, Італія та Іспанія. Особливості державної політики у даних країнах зорієнтовані у напрямку підвищення рівня ефективності різних сфер національної економіки, при цьому дані країни за пріоритетну ціль ставлять дотримання високого рівня безпеки.

Серед нових країн, які приєдналися до Європейського союзу, а саме: Болгарії, Польщі, Румунії, Словаччини, Чехії, Угорщини відбувається завершення реформи системи забезпечення економічної безпеки держави.

\section{6. Висновки з дослідження}

Механізм державного управління процесом забезпечення економічної безпеки історично сформувався в Україні у складі СРСР у межах державної безпеки, був іiі підсистемою, який не відокремлювався і окремо не визначався у концептуальних, законодавчих та програмних документах.

Правові передумови формування економічної безпеки України були закладені Декларацією про державний суверенітет України, Законом УРСР «Про економічну самостійність України», Конституцією України Закону України «Про основи національної безпеки України».

Проведений аналіз результатів наукових досліджень вітчизняних і зарубіжних фахівців та практики державного управління дозволяє зробити висновок, що теоретична база концептуальних основ економічної безпеки має на сьогодні все ще недостатній ступінь розробленості. Існують значні розбіжності у підходах до визначення сутності та понятійного апарату механізму державного управління економічною безпекою країни.

Опрацювання теоретичних основ економічної безпеки надало можливість систематизувати вимоги щодо формування сутності, змісту, структури економічної безпеки держави. Вони повинні містити орієнтири та цілі системи державного управління з можливостями кількісного виміру іiі рівня, а також обумовлювати механізми забезпечення економічної безпеки України. Визначення економічної безпеки 
повинно враховувати вимоги чинної системи національної безпеки України, бути органічно вбудованою підсистемою, бути стислим i ємним.

Теоретичні узагальнення сутності категорії «економічні інтереси» визначають їх спрямованість на одержання економічних переваг особи, суспільства і держави, забезпечення умов існування й розвитку, економічної незалежності і збагачення. Підставою для формування загроз економічній безпеці є фактори або умови, стан або тенденції, цілеспрямована, випадкова, помилкова діяльність або бездіяльність.

Правове забезпечення економічної безпеки України недостатнє. Адресні нормативно-правові документи - концепція, стратегія, державна програма економічної безпеки - розробляються в державі впродовж восьми років та й досі залишаються не прийнятими. Суттєві недоліки має чинне законодавство, спрямоване на забезпечення економічної безпеки. У Концепції національної безпеки України відсутня збалансованість у структурі та у співвідношенні пріоритетних економічних інтересів, економічних загроз, основних напрямів забезпечення економічної безпеки. Вирішення складних завдань сучасного державотворення потребує врахування світового досвіду розв'язання проблем забезпечення економічної безпеки, переймання з нього позитивних елементів та попередження негативних.

Таким чином, економічна безпека держави - це система, що складається з взаємопов'язаних та комплементарних елементів (компонентів), а рівень економічної безпеки держави залежить від безпеки кожної з них. Крім того, ми вважаємо, що всі дискусії, в яких йдеться про те, що одне з вищезазначених компонентів $є$ більш-менш важливим, і більшу увагу слід приділити державній безпеці. Державна економічна безпека є складною концепцією, і вся безпека пов'язана 3 окремими рівнями безпеки своїх компонентів. Тому головним завданням держави є забезпечення належного рівня безпеки для кожного компоненту державної економічної безпеки, через який буде забезпечена державна економічна безпека. Слід також зазначити, що постійні зміни у світі, що відбуваються навколо політичних, економічних, соціальних, військових та інших питань, також змінюють характер і зміст загроз економічної безпеки, і вони вимагають одночасних та одночасних змін у політиці державна економічна система безпеки. 


\section{Hbur Zoriana}

\section{Список літератури:}

1. Деренуца, А.С. Анализ опыта стран Европейского союза в сфере обеспечения национальной экономической безопасности [Електронний pecypc] / Портал : Global international scientific analytical project. - Режим доступу: http://gisap.eu/ru/node/172.

2. Мельник В. І. Зарубіжний досвід забезпечення економічної безпеки держави (на прикладі країн Східної та Центральної Європи) / В. І. Мельник // Науковий вісник Академії муніципального управління. Серія : Право. - 2015. Вип. 1 (2). - С. 50-57.

3. Данилишин Б.М. Безпека регіонів України і стратегія ії гарантування: Б.М. Данилишин, А.В. Степаненко, О.М. Ральчук та ін. / за ред. д-р екон. наук, проф., чл.-кор. НАН України Б.М. Данилишина. - К. : Вид-во «Наук, думка». 2008. - T. 1. -392 c.

4. Желюк Т. Економічна безпека в системі інституційного вектора збалансованого розвитку [Текст] / Тетяна Желюк // Вісник Тернопільського національного економічного університету. - 2013. - Вип. 1. - С. 19-32.

5. Левчук О.В. Економічна безпека України в контексті глобалізаційних викликів. Економіка і суспільство. 2017. Випуск № 8, с. 59-64.

6. Матвійчук I. О. Інституціоналізація управління економічною безпекою держави / I. О. Матвійчук // Вісник Академії митної служби України. Сер. : Економіка. - 2012. - № 2. - С. 131-141.

7. Притула Н. В. Досвід забезпечення економічної безпеки в зарубіжних країнах / Н. В. Притула // Економіка та управління національним господарством: стан, тенденції та перспективи: Тези доп. I Міжн. наук.-практ. конф. Одеса: Пальміра, 2014. - С. 41-44.

8. Пугач О.А. Світовий досвід упередження загроз економічній безпеці національної економіки / О.А. Пугач // Науковий вісник Херсонського державного університету. - Випуск 12. (Ч. 3). - 2015. - С. 43-46.

9. Скорук О. В. Економічна безпека держави: сутність, складові елементи та проблеми забезпечення / О. В. Скорук // Науковий вісник Ужгородського національного університету. Серія : Міжнародні економічні відносини та світове господарство. - 2016. - Вип. 6(3). - С. 39-42.

10. Ocepek A. Economic Security and the European Dream [Електронний pecypc] / Anthony Louis Ocepek // Портал : Saint Anselm College. - Режим доступу: http://www.anselm.edu/Documents/NHIOP/Global\%20Topics/2010/ Ocepekpaper.pdf.

11. Schwab K. The Global Competitiveness Report / K. Schwab // World Economic Forum. $-2017 .-400$ p.

\section{References:}

1. Derenutsa, A.S. Analysis of European Union experience in the field of national economic security [Electronic resource], Portal: Global international scientific analytical project, available at: http://gisap.eu/ru/node/172.

2. Mel'nyk V. I. (2015) Foreign experience in providing economic security to the state (for example, the countries of Eastern and Central Europe), Naukovyj visnyk Akademii munitsypal'noho upravlinnia. Seriia : Pravo, vol. 1 (2), pp. 50-57. 
3. Danylyshyn B.M. (2008) Bezpeka rehioniv Ukrainy i stratehiia ii harantuvannia [The security of the regions of Ukraine and the strategy of its guarantee], Naukova dumka, Kyiv, Ukraine.

4. Zheliuk T. (2013) Economic security in the system of the institutional vector of balanced development, Visnyk Ternopil's'koho natsional'noho ekonomichnoho universytetu, vol. 1, pp. 19-32.

5. Levchuk O. V. (2017) Ukraine's economic security in the context of globalization challenges, Ekonomika i suspil'stvo, vol. 8, pp. 59-64.

6. Matvijchuk I. O. (2012) Institutionalization of the management of the economic security of the state, Visnyk Akademii mytnoi sluzhby Ukrainy. Ser. : Ekonomika,, no. 2, pp. 131-141.

7. Prytula N. V. (2014) Experience in providing economic security in foreign countries, Ekonomika ta upravlinnia natsional'nym hospodarstvom: stan, tendentsii ta perspektyvy: Tezy dop. I Mizhn. nauk.-prakt. konf, pp. 41-44.

8. Puhach O.A. (2015) Critical experience in preventing threats to the economic security of the national economy, Naukovyj visnyk Khersons'koho derzhavnoho universytetu, vol. 12(3), pp. 43-46.

9. Skoruk O. V. (2016) Economic security of the state: the essence, constituent elements and problems of provision, Naukovyj visnyk Uzhhorods'koho natsional'noho universytetu. Seriia : Mizhnarodni ekonomichni vidnosyny ta svitove hospodarstvo, vol. 6(3), pp. 39-42.

10. Ocepek A. Economic Security and the European Dream, Sen-Ansel'm koledzh. URL: http://www.anselm.edu/Documents/NHIOP/Global\%20Topics/ 2010/Ocepekpaper.pdf.

11. Schwab K. (2017) The Global Competitiveness Report, World Economic Forum, p. 400. 